\title{
RISE OF ISLAMOPHOBIA IN GERMANY, FRANCE AND SWITZERLAND AFTER 9/11
}

\author{
11 Eylül Sonrası Almanya, Fransa ve İsviçre'de İslamofobinin Yükselişi
}

Asst. Prof. Dr. Oğuzhan YANARIŞIK*

Geliş Tarihi: 28.12.2017 Yayına Kabul Tarihi: 25.01.2018

\section{Öz}

11 Eylül 2001 terör saldırıları, batı dünyasında ırkçılık, yabancı düşmanlığı ve İslamofobi gibi köklü sorunların yükselişini hızlandıran çarpıcı bir dönüm noktası olmuştur. 11 Eylül sonrası dönemde yaygınlaşan düşmanca söylem ve tutumlar, Avrupa toplumlarında nefret tohumlarının filizlenmesi için uygun bir ortam meydana getirmiştir. Bu süreç, sadece Avrupa'da İslam karşıtı duyguları besleyen önemli bir faktör değil, aynı zamanda Avrupa'nın iç barış ve geleceği için bir tehdit unsuru haline gelmiş̧tir. Bu makale, üç farkı Avrupa ülkesinde bu sürecin örneklerini analiz etmektedir. Bu çalışmada Almanya ve Fransa Avrupa Birliği'nin en büyük ve en önemli üyeleri olarak seçilmiştir. İsviçre ise Orta Avrupa'da dünyanın en geliş̧siş ülkelerinden biri olduğu için özel bir örnek olarak seçilmiştir. Bu trendin kıtanın her köşesindeki, hatta parlayan örnekler olması gereken yerlerinde bile görülen, geniş kapsamlı etkilerini vurgulamak için bir örnek olarak kullanılmıştır.

Anahtar Kelimeler: İslamofobi, Avrupa, 11 Eylül Sonrası, Almanya, Fransa, İsviçre

\begin{abstract}
11 September 2001 terror attacks have been a dramatic turning point in the western world, which escalated the rise of deep rooted problems such as racism, xenophobia and Islamophobia. Hostile rhetoric and attitudes in post-9/11 era provided a suitable environment for the sprouting seeds of hatred in European societies. This process is not only an important factor in feeding antiIslam sentiments in Europe, but also a threat for the inner peace and future of Europe. This article analyses the examples of this process in three different European countries. Germany and France are chosen in this article as the biggest and most important members of the European Union. Switzerland was picked as a special case in central Europe as one of the most developed countries in the world. It is used as an example to show the far-reaching influences of this trend in every corner of the continent, even in those places that are supposed to be the shining examples.
\end{abstract}

Keywords: Islamophobia, Europe, Post-9/11 Era, Germany, France, Switzerland

\footnotetext{
* Erzincan University, Department of International Relations, yanarisik@gmail.com, Orc1d.org/ 0000-0003-3442-4779
} 


\section{INTRODUCTION}

The European Union project opened the way for an unprecedented era of peace and prosperity among European countries for over five decades. In spite of this achievement, the roots of concepts such as racism, xenophobia and Islamophobia reach deep into the history of Europe. Indeed, these dangerous ideologies gave some of its bloodiest fruits on the European territory, with cases like colonialism, religion wars and the slaughter perpetrated by the German Nazis based on the belief about supremacy of Aryan race. The seeds of these ideational bases that prepare the ground for such cruel practices have fallen asleep in the cultural memories of some marginal segments of European societies. When they have found a fertile social and political environment in recent years, especially after $9 / 11$ terror attacks, these seeds have re-sprouted alongside the rise of far-right political parties all around Europe.

This trend gained speed with rhetoric that associated terrorism with Islam in general. All types of hostility, including physical attacks, against Muslims living in Europe has increased. For example, more than 300 attacks against Muslims took place in UK alone, in the immediate aftermath of September 11. According to a poll held during this period, 26 percent of Britons thought that Islam is a threat to Western values (Travis, 2001). In some other European countries, the situation was even worse.

The first large-scale social explosion of this attitude that had been rising beneath the surface happened because of a short film titled Submission by Dutch producer and director Theo van Gogh in 2004. The film consisted of stories told by a woman, who prayed naked with the Qur'an al-karîm verses written on her body. Ayaan Hirsi Ali, the film's script writer, was a female Dutch politician who claimed to have abandoned Islam after 9/11 terrorist attacks. This has increased the provocative tone of the film's message.

While depicting Islam as a bad religion, the film was attributing the actions of terrorists to all Muslims. Thus the film caused outrage in Muslim countries, with protests on the streets. Film's director Gogh was killed by a terrorist, who was a Dutch citizen of Moroccan descent. Thereupon, 47 mosques were set on fire and 106 other buildings 
owned by Muslims were attacked in the same month, according to the European Monitoring Centre on Racism and Xenophobia. Besides, it has become commonplace to insult Muslims on the streets, in public transport vehicles and even during sport events. Anti-Islam leaflets were distributed in various parts of Netherlands. As a result, the film played into the hands of radical groups on both sides and led to the outbreak of intense violence. The Washington Times labelled these incidents as "mini-clash of civilizations" (Borchgrave, 2004).

Another incident happened when Danish newspaper Jyllands-Posten published insulting cartoons depicting Prophet Muhammad as a terrorist on 30 September 2005. As has been pointed out by BBC Arab Affairs analyst Magdi Abdelhadi, "the association of the Prophet with terrorism [has been very] offensive to the vast majority of Muslims." The newspaper claimed that it was doing this in order to criticise Islam. Despite reactions from different parts of Muslim world, cartoons were re-released in various European countries in an inflammatory manner. This further aggravated anger in countries with Muslim populations. Various buildings owned by Western institutions were attacked in these countries. Danish embassies were set on fire in Syria, Lebanon and Iran. In Abdelhadi's words, these reactions were linked to "America's war on terror," since it "is still largely perceived in the Arab world as a war on Islam" (Abdelhadi, 2006).

Prime Minister Anders Fogh Rasmussen described the situation as the biggest international crisis for Denmark since the Second World War. But he refused to apologise as had been asked by Muslim societies, claiming cartoons were within the boundaries of press freedom. However leaders like French President Jacques Chirac stated that the cartoons were clear sources of provocation and opposed their publication. Yet some other politicians were keen to add fuel to fire. For example, Italian Minister Roberto Calderoli was wearing t-shirts with these cartoons printed on.

Controversial Regensburg lecture of Pope Benedict XVI became another source of tension between Muslim and Christian worlds. During his speech delivered at the University of Regensburg in Germany on 12 September 2006, the Pope quoted an unfavourable remark about Islam, which was made at the end of the 14th century 
by the Byzantine emperor Manuel II Palaiologos: "Show me just what Muhammad brought that was new and there you will find things only evil and inhuman, such as his command to spread by the sword the faith he preached." Muslim politicians and religious leaders immediately protested against what they perceived as an insulting mischaracterization of Islam.

The Organization of the Islamic Conference declared it "regrets the quotations cited by the pope on the Life of the Honorable Prophet Muhammad," and continued: "The attribution of the spread of Islam around the world to the shedding of blood and violence, which is 'incompatible with the nature of God' is a complete distortion of the facts, which shows deep ignorance of Islam and Islamic history" (CNN, 2006-a). Thousands of Muslims rallied in protest at the comments in various countries.

Leaders from Muslim countries have called on the Pope to apologize for his remarks. For instance, Malaysian Prime Minister Abdullah Ahmad Badawi said "The Pope must not take lightly the spread of outrage that has been created," and urged the Pope to apologize and withdraw his controversial comments (CNN, 2006-b). Pakistan's parliament issued a statement saying "The derogatory remarks of the Pope about the philosophy of jihad and Prophet Muhammad have injured sentiments across the Muslim world and pose the danger of spreading acrimony among the religions" (BBC, 2006-a). Muhammad Hamid Ansari, Vice-President of India, said: "The language used by the Pope sounds like that of his 12 th-Century counterpart who ordered the crusades" (CNN, 2006-b).

As a reaction to what Michael Hirst from The Telegraph describes as "apparently disparaging remarks about Islam," then-Turkish Prime Minister Recep Tayyip Erdoğan also said "I believe it is a must for (the Pope) to retract his erroneous, ugly and unfortunate remarks and apologise both to the Islamic world and Muslims. ...I hope he rapidly amends the mistake he has made so as not to overshadow the dialogue between civilizations and religions." In Hirst's words, Erdoğan's “comments were a milder version of the angry outpourings from Muslim leaders around the world" (Hirst, 2006). 
After angry reactions from throughout the Muslim world, the Pope apologised and said the medieval text which he quoted did not express his personal opinion. He also added a footnote to his controversial quotation: "In the Muslim world, this quotation has unfortunately been taken as an expression of my personal position, thus arousing understandable indignation. I hope that the reader of my text can see immediately that this sentence does not express my personal view of the Quran, for which I have the respect due to the holy book of a great religion" (The Pope Benedict XVI, 2006). However, the damage of the controversy over the relations between Muslim and Christian societies has been considerably high at the end of the day.

Another Islamophobic provocation came with a short film titled Fitna, by Dutch politician Geert Wilders released in 2008. The film presented the Qur'an verses alongside images of terrorist attacks and suggested tearing apart some pages of the holy book. The film ended with the following call to all Europeans: "In 1945, Nazism was beaten in Europe. In 1989, Communism was defeated in Europe. Now the Islamic ideology has to be defeated. Stop Islamisation" (Amarasingam, 2009). Wilders should have beeen satisfied with the fame he earned with this film, since he announced that he would produce a sequel, which was prone to include further heavy insults to Prophet Muhammad. He blatantly went so far as to say that Fitna II would be about "the barbaric life and the sick mind of Muhammad" (Radio Netherlands Worldwide, 2011).

Another agitation in coming years took place in the United States. Terry Jones, a pastor in Florida, became the focus of global attention when he threatened to burn a copy of the Qur'an on the ninth anniversary of the September 11 attacks. This unknown pastor of a small church, who is also the author of a book titled Islam is of the Devil, became famous throughout the world after this provocative proposal. He was directly addressed by the most senior officials, including U.S. President Barack Obama, Secretary of State Hillary Clinton and Defense Secretary Robert Gates. He appeared in major media channels. General David Petraeus, commander of coalition forces in Afghanistan, warned that such a provocative action could jeopardize the lives of American soldiers working in foreign offices. In response to threat, protests were organised in various countries like Afghanistan and 
Indonesia. Finally, under pressure from the American administration, priests and his small community abandoned this plan.

But a few months later, in March 2011, the same priest burned a copy of the Qur'an after a symbolic self-organized court hearing. This ignited demonstrations in Afghanistan, which lasted many days, causing more than twenty-five casualties. American officials claimed that the priest's action is not contrary to the law and within the scope of freedom of expression. Thus, they rejected taking any legal action against him. However, this has been perceived as a provocative act by Muslims all around the world, which clearly reflects hatred against Islam. South African journalist Tony Karon was drawing attention to similarities between media strategies used by al-Qaeda and this priest. In his words, Terry Jones managed to become famous by this "welltimed provocation, [which was] designed to stoke the fires of Muslim-Christian enmity like Osama bin Laden tried to do" (Karon, 2010).

Since there has not been any legal sanction against such insults, similar examples have repeated in several other places. In France, a blogger named Ernesto Rojas Abbate filmed himself burning a copy of the Qur'an and urinating on it to put out the flames. In the video he was using pages of the Qur'an "as a prop in a simulation of the September 11, 2001 terrorist attacks." He published these images on his website in order to strengthen his action's impact. Islamic Council of France filed a criminal complaint about this person for "insulting the religious feelings" of Muslims. However, the court did not find the defendant guilty on the grounds that his action was within the boundaries of freedom of expression, although it confirmed that the video was "wilfully outrageous and deliberately provocative" (Agence France-Presse, 2011).

Western media broadly questioned such acts only when U.S. Ambassador to Libya Chris Stevens and three other Americans in the Libyan city of Benghazi were killed after publication of another provocative film named "Innocence of Muslims." In CNN's words, the film was portraying Prophet Muhammad as "thug, womaniser, child molester, homosexual and ruthless killer" while depicting Islam "as a fraudulent religion" (CNN, 2012). 
In its 14 minute trailer, the last words of a Jew, who was supposedly killed by Prophet Muhammad, was asked. He turned to his wife and said: "Sofia, this is my will: God remembers the Jews and brings them together in the Holy Land. I hope the He won't forget our bones. And I wish Muhammad's sons are given a restitution for their grandfather's blood for the rape of our women for our children and our riches." As has been put by Professor John Esposito from Georgetown University, the film played "right into the hands of extremists in the region who are using anti-American sentiment to advance their own goals" (Huus, 2012). And extremists did not miss the chance to exploit such provocations to advance their own goals through violence.

UN Secretary General Ba Ki Moon described the film as "hateful and disgusting" and added: "It is shameful to exploit the fundamental right to free expression by deliberately provoking bigotry and bloodshed. It is also wrong to exploit the anger; this only feeds the cycle of recrimination and senseless violence" (Moon, 2012).

"Such a demonization in a post-9/11 world" also resonated in comments of people like Brigitte Gabriel, "a potent public speaker" (Welch, 2012: xi) who was addressing a cheerful crowd in the Tea Party convention in fall of 2010 and warning them by saying: "America has been infiltrated on all levels by radicals who wish to harm America. They have infiltrated us at the C.I.A., at the F.B.I., at the Pentagon, at the State Department. They are being radicalized in radical mosques in our cities and communities within the United States" (Goodstein, 2011).

As the founder of ACT! for America, an organisation with 150.000 members who claim to be "self-appointed terrorism detectors," Gabriel was describing their motivation by claiming that there is a "cancer" infecting the world. In her words, "This cancer is called Islamofacism. This ideology is coming out of one source: The Koran" (Gabriel, 2006: $\mathrm{xxv}$ ).

As a result, such hostile rhetoric and attitudes created a suitable environment for the sprouting seeds of hatred in European societies. This process is not only an important factor in feeding anti-Islam sentiments in Europe, but also a threat for the inner peace and future of Europe. At this point, some examples may help in explaining this 
troublesome trend in some European countries. Germany and France are chosen in this article as the biggest and most important members of the European Union. Switzerland was picked as a special country in central Europe as one of the most developed countries in the world, while ranking "at or near the top globally in several metrics of national performance, including government transparency, civil liberties, quality of life, economic competitiveness, and human development" (Abbott, 2017). It is used as an example to show the far-reaching influences of this trend in every corner of the continent, even in those places that are supposed to be the shining examples.

\section{GERMANY: “WE FAILED MULTICULTURALISM"}

In the post-9/11 era, it has become an increasingly prevalent attitude in Germany, like many other European countries, to speak and write against immigrants, especially Turks (Yanarışık, 2013). For example, politicians like Horst Seehofer argued that immigrants from Turkey and Arab countries have difficulties in integrating Germany. Top-level figures like Volker Kauder, chairman of the parliamentary group of the ruling Christian Democratic Party, claimed that "Islam is not part of [German] tradition and identity... and so does not belong to Germany." According to Interior Minister Hans-Peter Friedrich, who believes that Germany's identity has been "shaped by Christianity and the Enlightenment," said "that Islam is part of Germany is a fact that cannot be proven by history" (Zand, 2012).

Similar views have been expressed in a much more severe tone by Thilo Sarrazin, a Social Democratic Party (SPD) member and former board member of the Bundesbank. With over 1.5 million copies sold, his controversial book titled "Germany Abolishes Itself" (Deutschland schafft sich $a b$ ), which attacked post-war immigration policy and multiculturalism efforts of Germany, became the best-selling non-fiction book of a German policy-author of the decade (Der Spiegel, 2010). According to Sarrazin, Muslims have more problems assimilating in Europe than other immigrants. He also thinks that Turkish and Arab immigrants are overly dependent on the state and are making Germany "dumber" (Randow and Vits, 2010). These sentences summarise his attitude towards immigrants: 
"Integration requires effort from those that are to be integrated. I will not show respect for anyone that is not making that effort. I do not have to acknowledge anyone who lives by welfare, denies the legitimacy of the very state that provides that welfare, refuses to care for the education of his children and constantly produces new little headscarf-girls. This holds true for 70 percent of the Turkish and 90 percent of the Arab population in Berlin" (Maiello, 2011).

In return for such views, the neo-Nazi party NPD offered him presidency of the Party in Berlin.

His book's sale success showed that his ideas are far from being forgotten in German society. In fact, a public survey conducted by the Emnid polling institute on behalf of the Bild am Sonntag newspaper found that almost every fifth German would (18 percent) vote for a new party under Sarrazin's leadership. The survey also showed that 51 percent of Germans supported Sarrazin's views (Berliner Morgenpost, 2010). Klaus-Peter Schöppner Emnid CEO said, for these respondents Sarrazin was someone "who finally speaks what many think" (Die Welt, 2010).

Mainstream politicians, who are influenced by the growing public support for such ideas, started using a similar dangerous rhetoric, instead of opposing them. German Chancellor Angela Merkel was amongst them. In a gathering of younger members of her conservative Christian Democratic Union (CDU) party on 16th October 2010, Merkel told that "the approach [to build] a multicultural [society in Germany] and to live side-by-side and to enjoy each other... has utterly failed." Merkel's this comment was one of the many contributions from mainstream politician to inflame the rising anti-immigration feeling in Germany. As a matter of fact, a recent survey was suggesting more than $30 \%$ of Germans believed the country was "overrun by foreigners". Another public opinion poll by the Friedrich Ebert Foundation was showing that 30 percent of the population believed that "immigrants came to Germany in order to abuse the possibilities of the welfare state" (BBC, 2010-c).

Hatred against the Turks in Germany did not remain only rhetorical, but also turned into action many times. In fact, there are many 
horrific attacks of neo-Nazi terrorist groups on Turks living in Germany. Many Turks, including women and children, were killed brutally in 1992 Mölln, 1993 Solingen and 2008 Ludwigshafen arson murders, 2004 Cologne Turkish street bombing, and a variety of unsolved murders, just to name a few.

One of the recent examples was revealed by chance in November 2011, after discovery of a neo-Nazi cell whose members were responsible for a crime wave reaching back more than a decade that includes the murders of nine immigrants, eight of whom were of Turkish origin. The killings, in the words of German Interior Minister Hans-Peter Friedrich, were signs of "a new form of right-wing-extremist terrorism." Allegations surfaced in German newspapers that cell members "may have worked as confidential informants for Germany's domestic intelligence service." Chancellor Angela Merkel said the crimes revealed "structures that we never imagined" (Kulish, 2011).

Investigators found a hit list of 88 political targets, most of whom were from Germany's Turkish and Islamic communities. Vice-President of Turkish-Islamic Union in Europe (Avrupa Türk İslam Birliği) Mahmut Aşkar, who was also amongst the 68 Turkish names in the list, expresses his frustration as follows:

"What concern me most are not these murders. As long as the hatred in the minds against Muslims and Turks continues, other versions of these events will happen. Blaming the neo-Nazi political party (National Democratic Party of Germany, NPD) for everything that has been happening in this country is wrong. All public opinion surveys show that there is prejudice against the Turks from up to 80 percent of the society. Neo-Nazi cells are known addresses. What scare me most are the unknown sources of this hatred" (Focus Haber, 2012).

Fully aware of the damage caused by its bad reputation about Hitler's racist massacres, German authorities entered a race to make statements expressing their grief after the outbreak of the scandal. Angela Merkel acknowledged that German police made many mistakes about preventing these murders and arresting the neo-Nazi killers. During her speech at Bundestag, she confessed that they were "horrified by the extent of this hatred and racism," while acknowledging that it was 
"a shock" for Germany and "a danger to [its] standing in the world" (Kirschbaum, 2011).

Federal Interior Minister Hans-Peter Friedrich and Justice Minister Sabine Leutheusser-Schnarrenberger also apologized for their failure in preventing neo-Nazi terror and promised to investigate the events thoroughly. All political parties in German parliament issued a joint declaration, which stated "We are deeply ashamed that, following the monstrous crimes of the Nazi regime, right-wing extremist ideology has spawned a bloody trail of unimaginable acts of murder in our country."

Bundestag President Norbert Lammert underlined the parliament's grief, shock and dismay at the murders, and said "We are ashamed that the federal and state law enforcement authorities were unable to uncover or prevent the crimes that were committed over a period of years" (Der Spiegel Online, 2011). Alongside many others, Sigmar Gabriel, chairman of the Social Democratic Party of Germany (SPD), was criticising the double standards against Turkish and Muslim immigrants by saying, "All the streets would be closed down; all the top officials would take action immediately [if Islamists had attacked Germans]. But none of this was done [in the present case]" (Hürriyet Daily News, 2011).

Hajo Funke, a German political scientist from the Free University of Berlin, support this claim by saying that the German authorities "trivialise" right-wing violence. He claims that the authorities worry more about so-called 'Islamist terrorists' than far-right groups that have done much more damage to German society with their crimes (The Economist, 2011). Public figures also show the imminence increasing threat from these groups. For instance, figures from Berlin based Amadeu Antonio Foundation show that more than 1400 people in East Germany were subjected to racist violence in a single year in 2010. According to The Federal Office for the Protection of the Constitution, the domestic intelligence service, there are around 25,000 people within far-right groups, of whom 9,500 could be violent (Canşen, 2011).

As a result of these attacks, debates arose in the media and German society about closing neo-Nazi party, NPD, which is actively operating 
in some regional councils. In fact, there was an application to German Federal Constitutional Court for NPD's closure in 2001. However, the court had rejected the application on the grounds that there are large numbers of German secret service agents among party leadership, and thus it cannot be determined which policy of NPD is shaped by them.

After a Workforce Acquisition Agreement, which was signed among Turkey and Germany in 1961, hundreds of thousands of Turkish workers were welcomed by German authorities with flowers. But a considerable portion of Turkish migrants feel as unwanted foreigners now. Some of them think that they have not faced the current social pressure ever in the past. Gravity of the threat has been accepted by Chancellor Angela Merkel herself, when she confessed that multiculturalism efforts have utterly failed in Germany. This increased the pace of negative developments in terms of legal difficulties and social pressure faced by immigrants. European leaders who claimed to achieve EU's main motto (i.e. United in Diversity) on European continent, seemed to have hardships in applying this principle even within their countries. Admitting this failure at such levels did nothing but damage the hopes about Europe's future.

Rising concerns of immigrants reflect this pessimism. Tayfun Keltek, founder and chairman of the democratically elected umbrella organisation for migrants in North Rhine-Westphalia (LAGA NRW) and board member in Cologne Branch of Social Democratic Party of Germany SPD, is only one of the examples. Keltek is a leading figure among German citizens with Turkish descent, who actively promoted the integration of immigrants to German society. Yet, his name was on the hit list of the Neo-Nazi terrorist cell that was revealed in 2011. He expresses his disappointment about the German official response to these extremist groups by saying "I had full trust on German state until now. But this trust has been damaged by the latest incidents and recent developments. We observe racist tendencies among all segments of German society, including but not limited to teachers, police officers, doctors and politicians. The West has been looking for an enemy since the collapse of Soviet Union and it has discovered Islam as a potential candidate. Perceptions about Muslims have changed after September 11 attacks. The approach of politicians and media provoke this enmity" (Haber7, 2011). 
Concrete results of this disappointment among immigrants have been observed in terms of labour mobility. Considerable amount of highly skilled Turkish migrants have left Germany in this framework. There are around 3 million people of Turkish origin in Germany and 700.000 of them carry a German passport. The number of Turks with German passport dropped for the first time in 2008, after steady growth for decades. This trend continued in the consecutive years. This alerted German authorities, who are aware of the possible dangers of this situation. For instance, German State Minister for Integration Maria Böhmer warned that "given the shortage of skilled labour, [Germany] cannot afford to lose the knowledge and qualifications of skilled immigrants." Hans Heinrich Driftman, President of The Association of German Chambers of Commerce and Industry, said that Germany will end up with a labour shortage of five million within the next 15 years, if it does not change the way it integrates its immigrants (Grieshaber, 2011).

\section{FRANCE: UNDERMINING BASIC VALUES OF EU}

"My country, France, my homeland, my land is again invaded by an overpopulation of foreigners, especially Muslims... I am fed up with being under the thumb of this [Muslim] population which is destroying us, destroying our country and imposing its acts" ${ }^{1}$ French Actress Brigitte Bardot

France has been another EU country that suffered from increasing xenophobia. It has been quite famous for its traditional opposition against Turkey's EU accession. Yet its discriminatory policies against other minority groups in recent years extended the fronts in its fight against others. The infamous French Roma repatriation programme was one of the recent examples, which was called by the EU Justice Commissioner Viviane Reding as "disgrace" (BBC, 2010-b). The deportation programme came after the riots that arose in retaliation for the killing of a 22-year-old French Romani man by French police in July 2010.

\footnotetext{
${ }^{1}$ Brigitte Bardot was convicted in 1997, 1998, 2000, 2003 and 2008 for inciting racial hatred in various written articles and comments. Statements above are cited in Daily Mail, "Brigitte Bardot fined $£ 12,000$ for racial hatred after claiming Muslims are destroying France," 3 June 2008; and Reuters, "Brigitte Bardot on trial for Muslim slur," 15 April 2008.
} 
French government's answer was gradually hardening its stance by demolishing illegal Roma camps and sending thousands of Roma residing without authorization back to their countries. In his Grenoble speech, Former President Nicholas Sarkozy said that he had asked the interior minister to "put an end to the wild squatting and camping of the Roma." As president, he promised that half of 539 illegal Roma camps in his country would be gone within three months.

Paris had the legal right to require Romanian and Bulgarian citizens to obtain resident permits for stays of more than three months until 2014, under the transition conditions set when both countries joined the EU. Applying systematic deportation policy against a specific ethnic group raised an international outcry. Some pundits like German journalist Ullrich Fichtner thought that what was happening in France "would most likely be referred to as 'ethnic cleansing' in less prestigious countries" (Fichtner, 2010).

One French MP even said, "the dismantling of camps and deportations were reminiscent of Nazi round-ups in France in the Second World War" (Samuel, 2010). United Nations Human Rights Council expressed its concern about "political speeches of a discriminatory nature in France," and urged French authorities to "avoid" such grouped deportations and "strive for lasting solutions" (BBC, 2010-a). Pope Benedict XVI criticized deportation of Roma migrants and called upon acceptance of people of all origins and nationalities.

Viviane Reding, Vice-President of the European Commission responsible for Justice, Fundamental Rights and Citizenship, said that she was "appalled" by French deportation policy and warned the French government about its legal consequences:

"This is a situation I had thought Europe would not have to witness again after the Second World War... Discrimination on the basis of ethnic origin or race has no place in Europe. It is incompatible with the values on which the European Union is founded. National authorities who discriminate ethnic groups in the application of EU law are also violating the EU Charter of Fundamental Rights, which all Member States, including France, have signed up to. I therefore find it deeply disturbing that a Member State calls so gravely into question, by the 
actions of its administration, the common values and the law of our European Union" (Reding, 2010).

José Manuel Barroso, President of the European Commission, told the European parliament that the rights of the 12 million-strong Roma community had to be protected and warned European leaders to steer clear of the racism and discrimination of the past (Traynor, 2010). Romanian Foreign Minister Teodor Baconschi asked French politicians not to use Roma as scapegoats for political advantage, and expressed his concern "about the risks of populism and xenophobic reactions” (Crumley, 2010).

These criticisms were not enough to convince French authorities to stand back. On the contrary, during presidential election campaign, politicians raced for having the most anti-immigration stance. Nicolas Sarkozy targeted freedom of movement, a basic EU value, and claimed that France would exit Schengen visa area, if the EU fails to clamp down on illegal immigration. Increase in the pace of immigrant influx as a result of social disruptions caused by the Arab Spring, worsened the situation. This augmented the Islamophobic tone in anti-immigration rhetoric. The French Interior Minister Claude Gueant, who was responsible for immigration, claimed that "all civilisations are not of equal value," while stressing the need to "protect [French] civilisation" from foreign intruders (Al Jazeera English, 2012).

Political debates during the presidential election campaign, showed how deep the impact of post- $9 / 11$ security discourses on shaping western public opinion is. When Muhammad Merah, a 23-year-old French-Algerian, killed seven people, a few months before the elections, political arguments immediately focused on 'Islamist' threat. Sarkozy likened Toulouse shootings to $9 / 11$ by saying, "trauma caused by the killing in Toulouse are somewhat comparable to the (trauma) caused by the September 11 attacks in the United States" (Agence France Presse, 2012). This opened the way for several police raids at different locations, more social pressure on Muslims. Some Muslim leaders were banned from entering France for a conference, on the basis that they do "not share the country's values" (CNN Wire Staff, 2012). However, opposition parties described these moves as "a public relations stunt... and an electoral manoeuvre” by Sarkozy (Agence France Presse, 2012). 
In its editorial titled 'Mr. Sarkozy on the Low Road', The New York Times criticised Nicholas Sarkozy for "pander[ing] to racism and xenophobia" by "assailing foreign immigrants, foreign imports and even the dietary laws of French Muslims" in order to earn far-right votes (The New York Times, 2012). Other presidential candidates also used similar anti-Muslim discourses in their campaigns. For instance, Marine Le Pen, the presidential candidate of "the unabashedly xenophobic" National Front, complained that non-Muslims in Paris were unwittingly eating halal meat. And suddenly "halal meat" became one of dominating issues during the French presidential campaign. Not to be overshadowed by Le Pen, Sarkozy called for stricter meat labeling and linked the issue to civilisational concerns: "We have to consider our holidays, the church and cathedral towers in our villages and towns, our eating habits, our morality, as aspects of our civilisation not just our religion: the civilisation of the French Republic" (Flynn, 2012). Based on findings of a poll, he even claimed that halal meat was "the No. 1 worry of the French people" (Cody, 2012). Prime Minister Francois Fillon intensified the debate by suggesting that Muslims and Jews alike should abandon their slaughtering traditions, which he claimed did not "have much in common with today's state of science or hygiene" (Beardsley, 2012).

Sarkozy intensified his anti-immigration rhetoric, by promising to cut immigration by half during in five years. He openly said that there are "too many foreigners" in France (Borrud, 2012). Marine Le Pen, immediately replied by promising to cut legal immigration by 95 percent. This xenophobic and Islamophobic approach soon turned into anti-EU rhetoric in political campaigns.

At a giant rally, Sarkozy threatened to pull the country out of the Schengen passport-free zone, unless other EU members did more to control immigration from outside the area (The Economist, 2012). He also attacked EU trade rules, which he said had unleashed "savage" competition and he also threatened to act unilaterally, if the EU does not take necessary steps to protect European economies from the negative influences of foreign competitors. As has been put by political analyst Roland Cayrol, this kind of ultimatum pose a serious threat to the future of the European Union. Because, "rather than saying that France can only work in Europe, it's almost saying the contrary, that 
Europe must do what France tells it to, otherwise France will do so anyway" (Jarry and Guernigou, 2012).

Far-right leaders like Marine Le Pen, who got nearly one fifth of French votes in that presidential election and also the highest French vote in the last EP elections in 2014, are against EU membership form the very beginning. Le Pen describes the European Union as "a totalitarian structure and a rootless ... impotent empire." She names it as "the European Soviet Union" and promises to fight it with all her strength (Euronews, 2011). The popular support for such views in various European societies, keep sending worrying signals about the future of the EU. The defeat of Sarkozy because of the lack of support from Le Pen in the second round of presidential elections, reminded that its supporters could be the first victims of this rising xenophobic politics.

\section{SWITZERLAND: RESTRAINING RELIGIOUS RIGHTS}

Problematic situation in Europe about tolerance for religious rights of Muslims have become more prominent in the post-9/11 world. Several popular examples showed the magnitude of the decline in sympathy towards Muslims residing in European countries. One of the prominent incidents was the minaret referendum in Switzerland in 2009. A Turkish cultural association applied for permission to construct a minaret on the roof of its Islamic community centre in 2005. The first step towards controversy was taken by right-wing politicians mainly from the Swiss People's Party and the Federal Democratic Union on 1 May 2007 by the launch of a popular initiative that sought a constitutional ban on minarets.

The Federal Council opposed the initiative and recommended that initiative "against the construction of minarets" be rejected as inconsistent with fundamental principles and rights in the Federal Constitution. Justice Minister Widmer-Schlumpf declared that the minaret initiative was contrary to core human rights and was endangering the religious peace. Federal Councillor Eveline Widmer-Schlumpf said that a ban on minaret would be clearly contrary to the core values of Switzerland, while reminding that all other religious communities could build their buildings as they wish (Schweizer Radio DRS, 2009). 
Article 18 of The Universal Declaration of Human Rights says "Everyone has the right to freedom of thought, conscience and religion; this right includes freedom... to manifest his religion or belief in teaching, practice, worship and observance." It was problematic in itself to go to referendum about a human rights issue, since normally these are rights are not subject to public vote in democratic countries. Their boundaries cannot be constricted with any excuse including public vote. Human rights are commonly understood as "inalienable fundamental rights to which a person is inherently entitled simply because she or he is a human being" (Sepúlveda, et al: 3).

Although it was controversial enough to go to referendum on this subject; the issue became more complicated with attacks by far right groups on some mosques during the propaganda process. Some anti-minaret groups published online minaret attack games on the websites. The main target of the players was to shoot minarets in the game, in order to prevent the muezzin's call to prayer. Anti-minaret groups also distributed fliers that "feature a veiled woman against a background of a Swiss flag pierced by several minarets resembling missiles." These posters were denounced by The Federal Commission against Racism on the grounds that they "defame Switzerland's peaceful Muslim population, feed prejudice and portray the Muslim community as wanting to dominate Switzerland, oppress women and trample on fundamental rights" (CNN, 2009).

Figures like Ayaan Hirsi Ali, author of the screenplay for Theo van Gogh's movie Submission and a former member of the Dutch House of Representatives, interestingly claimed that "Swiss ban on minarets was a vote for tolerance and inclusion." While equating minarets with "political symbols used by Communists and Nazis" and mentioning "a wider international confrontation between Islam and the West" Ayaan Hirsi Ali showed that at least a group within the minaret ban supporters were seeing this issue as some sort of a battle and said, "In the battle of ideas, symbols are important" (Ali, 2009).

In spite of all warnings from the Swiss government, parliament and NGOs about the possible negative ramifications of a ban, the constitutional amendment banning the construction of new minarets was approved by $57.5 \%$ of the participating voters. Only four of the 26 
Swiss cantons opposed the initiative. Article 72 of the Swiss Federal Constitution now says: "The building of minarets is prohibited." In Ian Traynor's words, "banning minarets in a country [with a population of around 400,000 Muslims] that has only four mosques with minarets and no major problems with Islamist militancy, stunned the Swiss establishment," (Traynor, 2009) alongside Muslims all around the world.

Traynor, Europe editor of The Guardian, was not alone in having difficulty in understanding this ban. As expressed by Amila Buturovic, associate professor of religious studies at York University in Toronto, the minaret ban has been perceived by Muslims as "an unfortunate exhibition of Islamophobia." It was a serious warning about the xenophobic and Islamophobic tendencies among European nations. And the result of the referendum was a crushing defeat for the supporters of religious freedoms, since "the government, mainstream political parties, the churches, the main newspapers, the national president, the powerful business lobby, and the Vatican all opposed the ban." (Lewis, 2009).

Professor John Bowen from Washington University in St. Louis, Mo., said "The Swiss campaign played on people's fears," and added: "Just look at the posters that were used, with images of minarets, burkas and missiles. It was a phony association. The minarets have nothing to do with terrorism or political Islam or the maltreatment of women."

\section{CONCLUSION}

Apart from the examples mentioned above, far-right and far-left parties have continued to gain strong ground all across the European Union. Mainly as a result of such incidents in the post-9/11 world, hostile and xenophobic opinions on Islam were normalized in the eyes of the public by assessing them within the scope of freedom of expression. It has become more common to hold immigrants responsible for problems within the society. This opened the way to insult them, while degrading Islam and Muslims in public. First, some marginal parties have sought to exploit this inclination for the sake of short-term political interests. And then, broad-based political parties that are afraid of losing the votes of masses participated in this trend. By this way, 
mainstream political parties enabled these ideas to reach wider audiences. Rising economic problems in European countries exacerbated this process by strengthening xenophobic attitudes (Gabriel, 2006: xxv). Calamities like Charlie Hebdo attacks only worsened the situation. The disgraceful performance of European countries about Syrian refugee crisis has shown the severe damage of Islamophobic attitudes in European societies.

As a result, such hostile rhetoric and attitudes created a suitable environment for the sprouting seeds of hatred in European societies. This process is not only an important factor in feeding anti-Islam sentiments in Europe, but also a threat for the inner peace and future of Europe. As a sociologist, Welch uses "moral panic theory" in order to explain this trend: "moral panic over Muslims is understood as a popular demonology that produces folk devils at the local and national as well as international levels" (Welch, 2012: xi). From a similar perspective, George Morgan and Scott Poynting were observing that "in the global 'West', the radicalized 'Muslim Other' has become the pre-eminent 'folk devil' of our time." Although they accept that this process did not begin with 9/11, Morgan and Ponyting argue that this process has "expanded rapidly to reshape the politics of multiculturalism" in Western societies since then (Morgan and Poynting, 2012: 1). 


\section{REFERENCES}

ABDELHADI, Magdi (2006). "Cartoon Raw Highlights Deep Divisions," BBC News, 4 February.

Agence France-Presse (2011). "Court confirms acquittal of Frenchman who burned, urinated on Quran," 25 October.

, (2012). "Sarkozy likens Toulouse shootings to 9/11 as crackdown on Islamist militants nets 19 arrests," 30 March.

Al-Jazeera English (2012). "Sarkozy ally says all civilisations not equal," 5 February.

ALI, Ayaan Hirsi (2009). "Swiss ban on minarets was a vote for tolerance and inclusion," The Christian Science Monitor, 5 December.

AMARASINGAM, Amarnath (2009). "Film Review: Fitna," Journal of Religion \& Film 13, no.1 (April), http://www.unomaha.edu/jrf/vol13.no1/reviews/Fitna.htm (Accessed 27/10/2013).

BENEDICT XVI, The Pope (2006). "Lecture of the Holy Father - Faith, Reason and the University Memories and Reflections," Libreria Editrice Vaticana, 12 September.

BBC (2006-a). "Muslim anger grows at Pope speech," 15 September.

, (2006-b) "In quotes: Muslim reaction to Pope," 16 September.

_ (2010-a). “UN urges France to avoid Roma deportations," 27 August.

$\longrightarrow$ (2010-b). "EU may take legal action against France over Roma," 14 September.

— (2010-c). "Merkel says German multicultural society has failed," 17 October.

BEARDSLEY, Eleanor (2012). “In France, Politicians Make Halal Meat A Campaign Issue," NPR, 15 March.

Berliner Morgenpost (2010). "18 Prozent der Deutschen würden Sarrazin wählen," [18 percent of Germans would vote for Sarrazin], 6 September.

BORCHGRAVE, Arnaud de (2004). "Mini Clash of Civilizations," The Washington Times, 14 November. 
BORRUD, Gabriel (2012). "Sarkozy intensifies anti-immigration rhetoric," Deutsche Welle, 12 March.CANŞEN, Fulya (2011). "Aşırı Sağ Nasıl Hortladı: Görmedim, Duymadım, Bilmiyorum," [How did extreme right arise: I have not seen or heard and I do not know], Ntvmsnbc, 18 November.

CNN (2006-a). “Pope's Islam comments condemned," 15 September. , (2006-b). "Muslim fury grows at pope remarks," 16 September. , (2009). "Swiss vote to ban minaret construction," 29 November. , (2012). "Actress from anti-Islamic film: 'This makes me sick to my stomach', 12 September.

CNN Wire Staff (2012). "19 arrested in French police raids, Sarkozy says," CNN, 30 March.

CODY, Edward (2012). "In France, halal meat drama enters election campaign," The Washington Post, 6 March.

CRUMLEY, Bruce (2010). "France Deports Gypsies: Courting the Xenophobes?" Time, 19 August.

Daily Mail (2008). "Brigitte Bardot fined $£ 12,000$ for racial hatred after claiming Muslims are destroying France," 3 June.

Der Spiegel (2010). "Sarrazin bricht Verkaufsrekord," [Sarrazin breaks sales record], 29 October. , (2011). “German Parliament Condemns Neo-Nazi Terror,” 22 November.

Die Welt (2010). “Jeder fünfte Deutsche würde Sarrazin-Partei wählen,” [Every fifth German would choose Sarrazin party], 5 September.

Euronews (2011). “Interview: Marine Le Pen next French President?” 18 February.

FICHTNER, Ullrich (2010). “Driving out the Unwanted: Sarkozy's War Against the Roma," Spiegel Online International, 25 September.

FLYNN, Daniel (2012). "Sarkozy Courts French Far-Right Talking About Immigration, Halal Meat, Christian Roots," Reuters Blogs, 4 March.

Focus Haber (2012). "Hükümet 1rkçı teröre en iyi cevabı, göçmenlere eşit haklarla verebilir," [The best answer of the government against racist terror is to give equal rights to immigrants], 4 November. 
GABRIEL, Brigitte (2006). Because They Hate: A Survivor of Islamic Terror Warns America, St. Martin's Press, New York.

GOODSTEIN, Laurie (2011). “Drawing U.S. Crowds With Anti-Islam Message," The New York Times, 7 March.

GRIESHABER, Kirsten (2011). "Skilled Turkish immigrants leaving Germany," The Associated Press, 13 April.

Haber7 (2011). “Neonazilerin cinayet listesindeki 88 ismin 68'i Türk,” [68 out of 88 Names in Neo-nazi hit list are Turks], 27 November.

HIRST, Michael (2006). "Pope must withdraw his ugly remarks," The Telegraph, 17 September.

HUUS, Kari (2012). "Why films and cartoons of Muhammad spark violence," NBC News, 13 September.KARON, Tony (2010). "Koran Burning: Taking a Cue from Osama bin Laden?" Time Magazine, 8 September.

Hürriyet Daily News (2011). “Turkish killings draw wider neo-Nazi probe," 17 November.

JARRY, Emmanuel and Yann Le Guernigou (2012). “France's Sarkozy defies Europe with protectionist push," Reuters, 11 March.

KIRSCHBAUM, Erik (2011). “Merkel says neo-Nazi killings damage Germany's image," Reuters, 23 November.

KULISH, Nicholas (2011). "Neo-Nazis Suspected in Long Wave of Crimes, Including Murders, in Germany," The New York Times, 13 November.

LEWIS, Charles (2009). "Swiss vote to ban minarets a warning to Europe's Muslims," National Post, 30 November.

MAIELLO, Lia Petridis (2011). "Astonished by German Astonishment Over Nazi Attacks," Huffington Post, 22 November.

MOON, Ban Ki (2012). "Secretary-General's remarks to Opening Session of the General Assembly High-Level Forum on the Culture of Peace," New York, 14 September.

MORGAN, George and Scott Poynting (2012) Global Islamophobia: Muslims and Moral Panic in the West, Ashgate, Surrey. 
PHIPPS, Claire, Andrew Sparrow and Ben Quinn (2014). "European election results 2014: Ukip sweeps to victory in the UK," The Guardian, 26 May.

Radio Netherlands Worldwide (2011). "Wilders Announces Anti-Muhammad Film," 1 April.

RANDOW, Jana and Christian Vits (2010). "Weber to Debate Next Sarrazin Steps as Merkel Condemns Comments," Bloomberg, 1 September.

REDING, Viviane (2010). Press Release "Viviane Reding Vice-President of the European Commission responsible for Justice, Fundamental Rights and Citizenship Statement on the latest developments on the Roma situation," Reference: SPEECH/10/428, Brussels, 14 September.

Reuters (2008). "Brigitte Bardot on trial for Muslim slur," 15 April.

SAMUEL, Henry (2010). "UN warns France over Roma deportations," The Telegraph, 27 August.

Schweizer Radio DRS (2009). "Bundesrat: Minarett-Initiative widerspricht Verfassung", [Federal: minaret initiative contradicts Constitution], 15 October.

SEPÚLVEDA, Magdalena, Theo van Banning, Gudrún Gudmundsdóttir, Christine Chamoun and Willem J.M. van Genugten (2004). Human Rights Reference Handbook, 3rd edition, Costa Rica: University of Peace, Ciudad Colon.

The Economist (2011). "Neo-Nazi crimes in Germany: A horror from the past," 19 November.

, (2012). "The French election: An inconvenient truth," 31 March. , (2014). “The Eurosceptic Union,” 31 May.

The New York Times (2012). "Editorial: Mr. Sarkozy on the Low Road," 14 March.

TRAVIS, Alan (2001). “Attack on Afghanistan: ICM Poll," The Guardian, 21 October.

TRAYNOR, Ian (2009). "Swiss vote to ban construction of minarets on mosques," The Guardian, 29 November. 
, (2010). "Barroso makes veiled criticism of French anti-Gypsy campaign," The Guardian, 7 September.

WELCH, Michael (2012). "Foreword," in George Morgan and Scott Poynting (eds.), Global Islamophobia: Muslims and Moral Panic in the West, Ashgate, Surrey.

YANARIŞIK, Oğuzhan (2013). "Yükselen Irkçılık ve İslamofobi Gölgesinde Yaşayan Avrupa Türkleri: Almanya Örneği," [European Turks Living under the Shade of Xenophobia and Islamophobia: the Case of Germany], Yeni Türkiye, No:54, September-October, pp. 2911-2917.

ZAND, Bernhard (2012). "A Mecca in Europe: Why Islam Is an Integral Part of Germany," Der Spiegel, 8 June. 